\title{
Rural eco-museums: tourism development based on sustained development models
}

\author{
P. Miryousefi \\ Department of Architecture and Engineering, \\ Payam Noor University, Iran
}

\begin{abstract}
Aiming at revitalizing the subcultures, constructing the rural heritage ecomuseums began to take place as a far-reaching movement in European countries after the World War II. For the first time, this post-modern phenomenon took shape in Guilan and the Middle East in the year 2002. Guilan's Museum of Rural Heritage simulates and rejuvenates the cultural heritage of the Guilanians in an environment which is similar to the original point of Guilan's rural lifestyle. By gathering the cultural achievements of a diverse spectrum of ethnic groups in Guilan, this conglomerate familiarizes the people of Guilan with their ancestral past and identity. The profound and positive cultural, social, economic and environmental impacts of the rural eco-museums in the last 50 years demonstrate the conformity of the principles of these museums with the objectives of sustainable development. Despite being a newly-constructed complex, Guilan's Museum of Rural Heritage has achieved remarkable breakthroughs, including the revitalization and preservation of ethnic culture, attraction of popular participation and acquisition of the indigenous knowledge needed for the construction and management of such museums which can serve as a pattern for constructing similar museums all around Iran. Seven years of experience and study by the author in the position of Chairwoman of Workshop and Supervisor of the Architectural Studies and being in close contact with the trajectory of completion, circumstances and limitations of the project and her visiting of the successful and credible eco-museums in the world indicate that the construction of such museums is an undeniable necessity to expand the concept of sustainable development and sustainable architecture in the society.
\end{abstract}

Keywords: eco museum, de-assembling, re-assembling, rural heritage, sustainable tourism. 


\section{Introduction}

Eco-museums originate the conceptual transformation of cultural heritage and initiate the endeavors to preserve ethnic possessions in confrontation with the phenomenon of globalization through interaction with the environment and expansion of sustainable development.

It is not plausible to present a precise definition for this post-modern phenomenon which is aimed at evaluating the dynamism of ethnic heritage and natural resources with the participation of people. Eco-museums take shape on the basis of available facilities, cultural features and needs of a given region; however, from a general viewpoint, eco-museum is a collection designed to preserve the tangible and intangible heritage, nature, history, biological patterns and ethnic traditions, and promote them socially. Increasing the public awareness about the modernized concept of cultural heritage is one of the most essential objectives of eco-museums. This awareness propels us towards a comprehensive cognition, appreciation, evaluation and connection with our ethnic homeland.

The term "eco-museum" was first used by Hugues de Varine in 1971 to refer to the museums which were dedicated to the global environment.

"Eco-museum is a museum in which the point and location are defined and simultaneously the different places are exhibited according to the dimension of "time" and the transformation of a certain place in different temporal periods from the viewpoint of the lingual developments of a nation in the different periods of history" [2].

The other agreed definition is that "eco-museum describes the relationship between the human being and nature in the location and point of a specific site, consisted of a collection of acceptable scientific, cultural achievements which display the heritage of a group of people. It's a mirror in which people can see themselves" [2].

Anyhow, these are unconventional types of museums, which in contrary to the artistic museums that put on view the breakthroughs of upper social class, put on display the achievements of ordinary people and village dwellers; the image which these museums depict of the rural cultural heritage is greatly valuable for the regional habitants. In such museums, visitors get informed about the lifestyle of an ethnic group or tribe immediately.

Throughout the $19^{\text {th }}$ century, experts discovered the value of rural culture and that discovery underpinned the establishment of scientific anthropological museums. Constructed in 1873, the Nordiska museet in Stockholm was the first scientific anthropological museum ever built. In 1877, the National Museum of Finland was built in Helsinki and Dansk Folke museum was established in Copenhagen two years later in 1879. Skansen was the first open air rural cultural heritage museum to be built in 1891 in Sweden. This is the oldest and at the same time, the most scientific museum of this type in the world. The Eastern European countries also made efforts to establish such museums, being persuaded with strong political and ideological motives. The rural museums of Eastern Europe were constructed between the 1940s and 1950s with the intention of revitalizing the culture of proletarianism and agriculture [3]. 
Aiming at preserving the subcultures, respecting the environment and criticizing the thoughts of modernity, the idea of constructing such museums took shape as a far-reaching movement in the countries of Eastern Europe during the 1970s and 1980s. This movement was reinvigorated with the emergence of newly-born concept of sustainable development and sustainable architecture and turned into an all-encompassing phenomenon in these countries.

Structurally, museums fall under a number of categories: firstly, the preservation of regional buildings, local heritage and environment in the main area, where the ethnic habitants live in accordance with the original lifestyles of these houses. These museums are specifically called eco-museum. Secondly, it is the de-assembling and re-assembling of the constructions in a new environment which is in conformity with the original status and reminds the original point of establishment. In these museums, the main concern is the revitalization of the intangible elements of the culture. Such museums are generally called Open Air Museum. Primarily, these museums would only endeavor to replace the structures; however, with more experiences gained, exhibiting the styles of working and living of the original habitants and celebrating the rural festivities and rituals came on the agenda so as to present a more inclusive portrayal of the cultural heritage of the ancestors. With the developments of Open Air Museums, their diversity raised as well.

\section{Developments made by eco-museums}

Eco-museums have come to existence on the basis of late $19^{\text {th }}$ century's anthropological museums and turned into architectural phenomenon while being developed; however, during a 50-year historical period, they affected their surrounding environment to the extent that can be named prosperous social, economic and cultural phenomena. The improvement of ethnic people's lifestyle on the basis of sustainable development - without harming the environment and destroying the ethnic identity, growth of education and advancement of public awareness regarding the cultural heritage are all among the achievements of such museums. The transformation of evaluation criteria with regards to the apparatus and buildings in the eco-museums have underpinned the formation of scientific and research centers in the fields of architecture and rural anthropology.

The new phenomenon of evaluating ethnic, proletarian and agricultural culture have entered those scientific and museum-studying communities that would only conduct researches and studies about the preservation of artifacts, buildings and recording of events in the upper classes of the society. Ecomuseums made positive environmental effects and strengthened the region's economy wherever they were constructed [2-4].

\subsection{The environmental effects of the eco-museums}

1. Positive ecological and environmental impacts

2. Preservation of ethnic identity and connection of generations 
3. Empowerment of motives for preserving the ethnic architecture of the rural communities for living or attracting tourists to reside in

4. Revitalization of tangible and intangible cultural elements in the museum through staging ceremonies, traditional rituals, showcasing the styles of working and production by simulating gardens and traditional workshops

5. Reviving and revitalizing cultural elements in the rural communities through establishing constant connections with the local, rural councils

6. Contributing to the economy of the region by

- Attracting tourists and accommodating them in the renovated buildings or the museum's hotel

- Revitalizing traditional occupations and displaying them in the museum

- Creating jobs in the museum either directly or indirectly

- Selling the goods which have been produced in the museum traditionally

7. Popular participation

- The endowment of buildings, kitchen apparatus and agricultural instruments to the museum

- Voluntary cooperation with the museum by the students and the retired

8. Training

- The availability of museum's archive and library to the students, professors and scholars; gathering and documenting all of the information relevant to the buildings' de-assembling and re-assembling, customs and rituals in their original form would provide a unique background for conducting architectural researches and studying the rural culture

- Documenting the indigenous knowledge

- Holding educational workshops for the apprentices of different countries

- Teaching traditional skills to the youths and enthusiastic learners

- Holding round-the-clock camping for children and adolescents to teach them the traditional skills. This educational action penetrates the society through children and deepens the society's awareness of its cultural heritage as a result

- The familiarization of city dwellers (who do not have any connection with the natural environment of the villages) with rural life.

\section{Guilan's Eco-museum of Rural Heritage and the necessity of foundation}

Over the past century while Iran was enduring the pressures of new world's developments, the society underwent traditionalism in all of its forms. In this period, a transformation was swiftly made from the old to the new. The acceleration of developments towards modernism was so high to the extent that many cultural aspects evaporated. The Land Reform Law of 1963 which eliminated the feudalistic society and divided the lands between the farmers brought the rural communities into a new stage of production methods. Many farmers who could not afford the expenses of production immigrated to the 
cities. The emergence of revolution and war which was followed by devastative economic crises along with the wrong policies of the government in the expansion of rural communities caused the increased immigration of village dwellers to the cities, the growth of population and destruction of villages ever more. In these whereabouts, Guilan's earthquake of 1990 accelerated the destruction of rural buildings. Although the old houses were constructed strongly (on the basis of ethnic knowledge), the wrong policies of reconstruction led to the destruction of old houses. As the intangible elements of rural culture went down to demolition in this period of transformation, architecture suffered a lot accordingly. Currently, the construction of eco-museums seems to be the only remaining way for Iran to preserve the remnants of its ethnic cultural heritage.

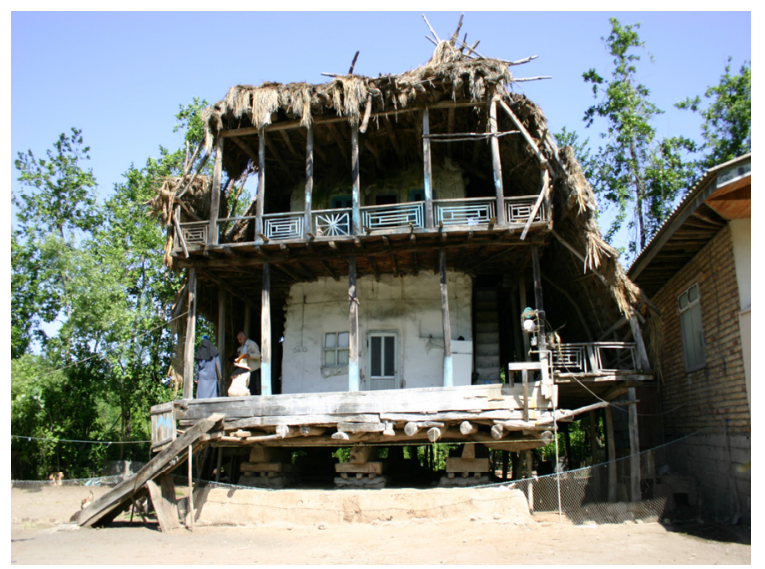

Figure 1: The house in the rural before de-assembling.

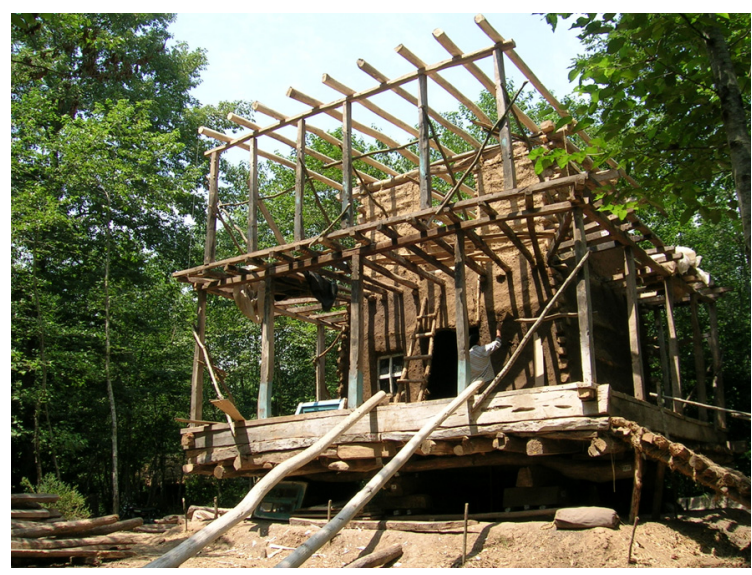

Figure 2: Re-assembling the eco-museum. 


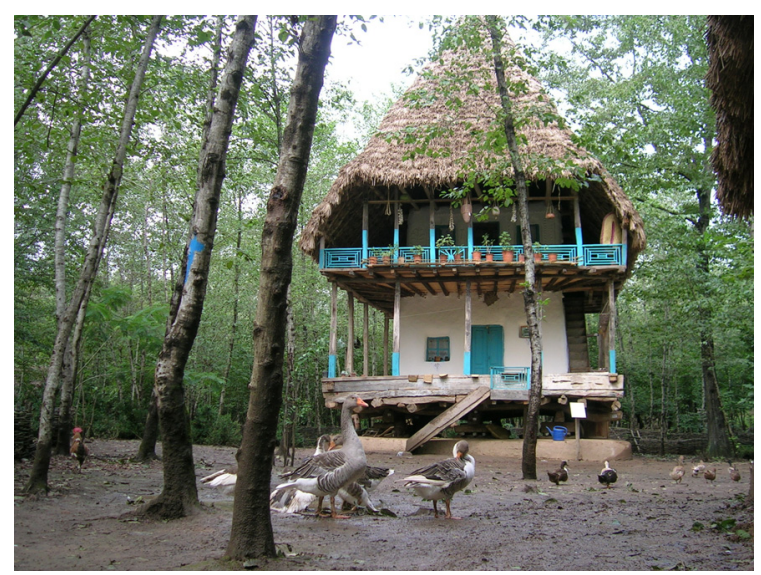

Figure 3: Re-assembled eco-museum.

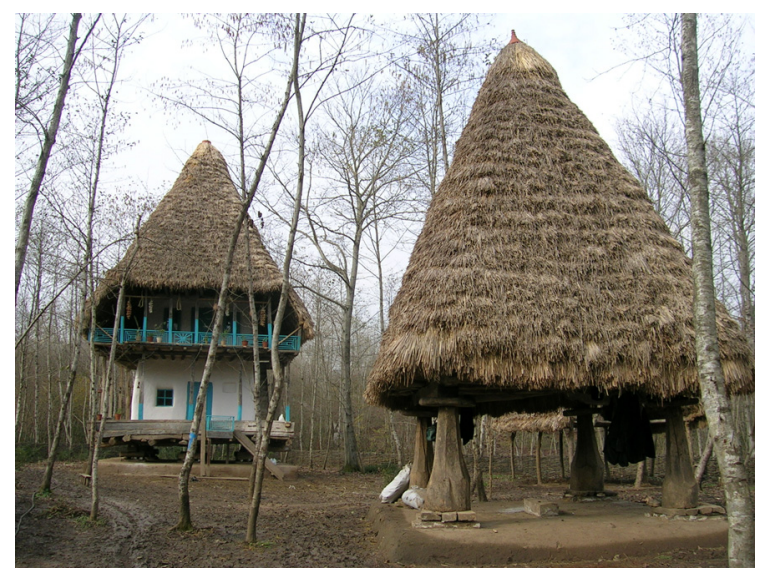

Figure 4: The house and re-assembled site.

With the objective of preserving rural heritage, the eco-museum of Guilan was constructed in one part of Guilan's jungles in the year 2004. This museum which has a surface area of more than 250 hectares, reassembled at least 150 rural houses in the site of museum, aimed at revitalizing the diverse and rich subcultures of various ethnic groups of Guilan. Attractive constructions such as stables, rice warehouses, agricultural farms, production workhouses, local bazaars and accommodation centers are located at the museum. At the moment, no more than $25 \%$ of the project is completed; however, the sections constructed in 2006 are available to the public. Although the museum is not too old and wellestablished, it has realized considerable cultural and social achievements to this point $[4,6]$. 


\subsection{Guilan's Eco-museum of Rural Heritage and ethnic identity}

At the beginning of exploration for the buildings between the years 2002 to 2006, an interesting point was revealed for us: the majority of villagers were disinclined to their culture and traditional houses. They would try to deny their roots as they would consider their homes dirty and underprivileged. In the common culture of people, "villager" is equivalent to "retarded"; therefore, the villagers who are the inheritors of this culture would refute it. It was not important for them that the remnant of these abandoned homes might be used to warm up stoves in the villages or endowed to the museum for reconstruction. Our endeavors to preserve these buildings seemed ridiculous and meaningless to them. Once the construction of the museum was over and the visitors gained access to it, the reality of this valuable and rich culture and the scientific, aesthetical capacities of the buildings were made known to everyone. The owners of the houses would show them to their relatives honorably and retell their ancestral roots enthusiastically. This feeling of honor towards the ancestral past and the sense of decisiveness to preserve the traditional constructions becomes more evident through the endowment of buildings, apparatus and instruments to the museum; moreover, this type of architecture has become a favorable pattern in the constructions regionally.

This evaluation is not limited to architecture and encompasses activities such as the celebration of wedding ceremony, local plays, reception with Guilani cuisines, guides wearing the local dresses and the exhibition of villagers' lifestyle in the museum which collectively make the society acquainted with the richness of this culture. These activities have contributed to the revitalization of intangible heritage and its circulation within the social strata. For the Iranian society which enjoys an intense ethnic diversity and suffers from the lack of documented resources to familiarize these ethnic groups with together, the existence of rural heritage museums is a necessity which can contribute to the resolution of misunderstandings, augmentation of mutual understanding and preservation of ethnic identity.

\subsection{Popular participation}

No eco-museum will be able to realize its objectives without popular participation. The participation of people is not an instrument towards progression; rather it is a goal in the route of planning for sustainable development. The managers of eco-museums actually play the role of scientific leader whilst the financial and social affairs of the museums are usually directed by the popular participation. The relationship between eco-museums and people is a mutual and two-sided connection. Popular participation contributes to the survival and continued existence of the museums and the museums spawn cultural and environmental values by functioning as an engine for the development of ethnic community. In the contemporary world of materialism where the values are estimated on the basis of material fundamentals, ecomuseums function as the elemental basis of economic development, hinged on the preservation of ethnic identity and natural features of the region. 
However and so forth, the extent of popular participation in the eco-museum of Guilan can be expanded potentially because the museum has not found its original position in the region yet.

- Primarily, all of the buildings would be purchased from their owners; however, numerous buildings have been endowed to the museum gratis since the museum's inauguration

- The NGO of museum fans handles the popular, self-directed supports of the museum

- A number of traditional customs and rituals are held by the villagers voluntarily [6].

- The patriarchs of the rural communities and local researchers provide the museum with their experiences and studies voluntarily [6].

\subsection{Economic impacts of the museum}

- Creating at least 100 direct jobs for the local experts and villagers in the scientific and operational fields.[6]

- Creating jobs for the region's villagers through reviving the traditional occupations in the bazaars, shopping stands and coffeehouses in the museum

- Buying construction materials from the villagers. These materials are locally produced and does not impose any cost on the inhabitants

- Attracting tourists (though the museum is still at the beginning of the itinerary in this field)

\subsection{Museum and education}

Documenting the unwritten, ethnic knowledge of the region has been one of the most prominent achievements of the Guilan's Museum of Rural Heritage. Having been disregarded previously, this knowledge is matchless technologically, aesthetically and from the viewpoint of its diversity. Acquiring and making indigenous the techniques of de-assembling and re-assembling the wooden structures and constructing an eco-museum in Iran which is an unprecedented event in the Middle East are among the breakthroughs of Guilan's eco-museum.

- Training skilled experts in different fields of anthropology, architecture, museum maintenance and management. Training ethnic human resources and expanding traditional skills

- Making available, to the students and researchers, the documents of the museum and results of the field researches into the buildings. It's not the objective of the museum to showcase the different types of houses or the styles of buildings and materials used in them; rather, it should represent an overview of the region's governing economic and social equations by introducing specific constructions and buildings such as farms. Therefore, the museum has assembled a wide spectrum of buildings, from the residence of the richest farmer to the house of the proletarian worker and this can help us 
comprehend and figure out the arrangement of social stratums within the rural community over the past two centuries

- Publication of museum's specialized journal ,'KANDOUJ'

- Training of the guides

- Holding workshops and seminars

- Compilation of scientific identification card for the artifacts

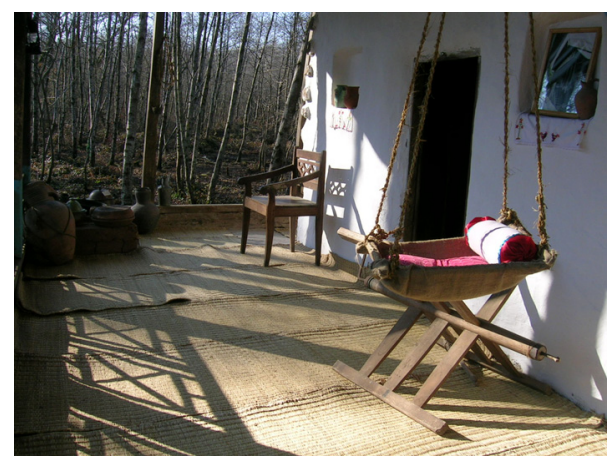

Figure 5: Original decoration.

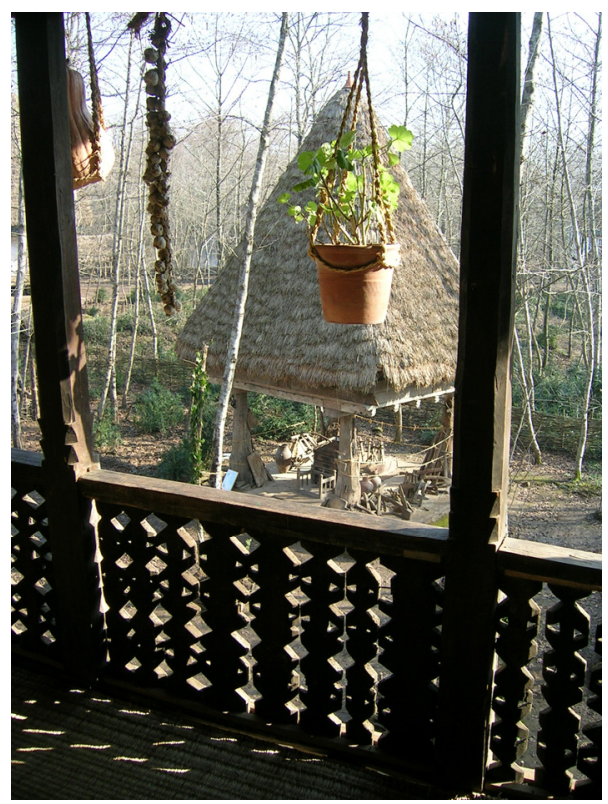

Figure 6: The houses in the eco-museum. 


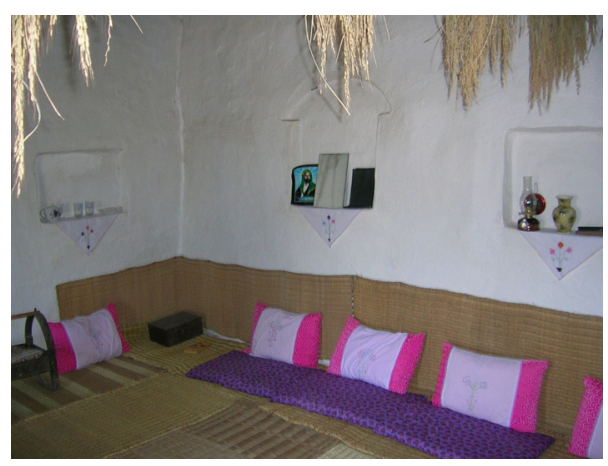

Figure 7: The houses in the eco-museum.

\section{Conclusion}

Despite being new phenomena in the course of human civilization, sustainable development and sustainable architecture are among the most important achievements of contemporary man which can help rescue the communities around the world from a number of social, environmental and identity-oriented crises.

These new concepts have their roots profoundly extended in the reflections and thoughts of those who are the originators of ethnic architecture. The concept of sustainable architecture can be developed through preserving and revitalizing the instances in the main sites and eco-museums as well as sampling for new constructions in the society. Eco-museums are powerful organizations which can improve the life of ethnic habitants by bringing into existence a sustainable economy and directing the industry of tourism towards sustainable patterns and meet the requirements of the local community consequently. The empowerment of social independence, identity and feeling of honor, resolution of the tribal misunderstandings through increasing the awareness of people about their past and present situation, preservation of environment and natural resources with the participation of people, sponsorship of educational programs specifically in respect of disseminating ethnic knowledge and formation of revitalization programs in order to increase the number of tourists and enhance the economy at the same time as protecting the ethnic values are among the goals and roles of eco-museums. Experience has demonstrated that constructing such museums can lay the groundwork for the realization of sustainable development and expansion of sustainable architecture in different societies, especially in the developing societies such as Iran which are moving from tradition to modernism.

\section{Resources and references}

[1] The author's 7-year-long experience and research as the Chairwoman of Workshop and Supervisor of the Architectural Studies at Guilan's EcoMuseum 
[2] Real, Barbara, "Eco-museum, an environmental treasure”, Kandouj magazine, No 1, pp 74-75, 2005

[3] Huwyler, Edwin, Open air museum of Ballenberg, translated by Faroogh Kharabi, Tehran, 2009

[4] Miryousefi, Pouya, Rural Heritage Museum of Guilan, MEMAR magazine, no 39, pp10-13, 2006

[5] Miryousefi, Pouya, "De-assembling \& Re-assembling houses of eastern plain of Guilan", Kandouj magazine, No 2, pp 25-43, 2006

[6] Archives of rural Heritage Museum of Guilan

[7] Guide du musee, Gutach, Jockers, Inge, pp 5-11, 2000

[8] Guide du musee, Ballenberg, Huwyler, Edwin \& Christian, Sidler, pp 3-12, 1999

[9] visited from: ECOMUSEE D'ALSACE, France; ECOMUSEE DE LA FORET NOIRE, Germany; ECOMUSEE DE LA FRANC-COMTOISE, France; MUSEE DE L'HABITAT RURAL BALLENBERG, Switzerland; OLD STURBRIDGE VILLAGE MUSEUM, USA; OPEN AIR MUSEM ARNHEM, Hollande 